4. Spotnitz W, Burks S. Use of tissue sealants in cardiac surgery. In: Franco K, Verrier E, editors. Advanced therapy in cardiac surgery. Hamilton, Ontario: BC Decker; 2003. p. 9-10.

5. Coselli JS, Bavaria JE, Fehrenbacher J, Stowe CL, Macheers SK, Gundry SR. Prospective randomized study of a protein-based tissue adhesive used as a hemostatic and structural adjunct in cardiac and vascular anastomotic repair procedures. J Am Coll Surg. 2003;197: 243-52; discussion 252-3.

6. Hewitt CW, Marra SW, Kann BR, Tran HS, Puc MM, Chrzanowski FA, et al. BioGlue surgical adhesive for thoracic aortic repair during coagulopathy: efficacy and histopathology. Ann Thorac Surg. 2000; 71:1609-12.

7. Raanani E, Latter DA, Errett LE, Bonneau DB, Leclerc Y, Salasidis
GC. Use of "BioGlue" in aortic surgical repair. Ann Thorac Surg. 2001;72:638-40

8. Passage J, Jalali H, Tam RK, Harrocks S, O'Brien MF. BioGlue Surgical Adhesive-an appraisal of its indications in cardiac surgery. Ann Thorac Surg. 2002;74:432-7.

9. Kazui T, Washiyama N, Bashar AH, Terada H, Suzuki K, Yamashita $\mathrm{K}$, et al. Role of biologic glue repair of proximal aortic dissection in the development of early and midterm redissection of the aortic root. Ann Thorac Surg. 2001;72:509-14.

10. LeMaire SA, Schmittling ZC, Coselli JS, Undar A, Deady BA, Clubb FJ, et al. BioGlue surgical adhesive impairs aortic growth and causes anastomotic strictures. Ann Thorac Surg. 2002;73: 1500-6.

\title{
New technologies for the treatment of type A aortic dissection: A case report
}

\author{
Stefano Saccani, MD, ${ }^{\mathrm{a}}$ Francesco Nicolini, MD, ${ }^{\mathrm{a}}$ Bruno Borrello, MD, ${ }^{\mathrm{a}}$ Andrea Agostinelli, MD, ${ }^{\text {a }}$ Pietro Larini, MD, \\ Carla Marcato, MD, and Tiziano Gherli, MD, ${ }^{\text {a }}$ Parma, Italy
}

A ortic arch replacement in the treatment of type A aortic dissection is justified in emergency settings to prevent later complications, ${ }^{1}$ even if it is technically demanding and affected by mortality and morbidity. ${ }^{2,3}$ Evolution of residual false lumen remains unpredictable, requiring further high-risk surgical procedures. We report a case of type A aortic dissection treated with ascending aortic replacement associated with a new stent graft positioned in the aortic arch and completed with thoracic endovascular stent graft placement.

\section{Clinical Summary}

A 78-year-old woman was admitted for acute type A aortic dissection. Preoperative transesophageal echocardiography showed a primary tear located above the aortic cusps and extending to the descending thoracic aorta. Cardiopulmonary bypass was established between the right subclavian artery and the right atrium. At mild hypothermia, the ascending aorta was crossclamped, and cold blood cardioplegia was administered through the coronary ostia.

From the Cardiac Surgery Department ${ }^{\mathrm{a}}$ and the Radiology Department, ${ }^{\mathrm{b}}$ University of Parma, Parma, Italy.

Dr Borrello was supported by a research grant from Compagnia di $\mathrm{S}$ Paolo-Torino and MIUR.

Received for publication Nov 24, 2003; revisions requested Dec 31, 2003; accepted for publication Jan 13, 2004.

Address for reprints: Francesco Nicolini, MD, Cattedra e Divisione di Cardiochirurgia, Università degli Studi, Via A. Gramsci 14, 43100 Parma, Italy (E-mail: francesconicolini@libero.it).

J Thorac Cardiovasc Surg 2004;127:1821-3

$0022-5223 / \$ 30.00$

Copyright $\odot 2004$ by The American Association for Thoracic Surgery

doi:10.1016/j.jtcvs.2004.01.020
The proximal aortic stump was reconstructed with continuous mattress sutures and Teflon collars after gelatin-resorcin-formol glue application to the false channel. At a nasopharyngeal temperature of $24^{\circ} \mathrm{C}$, general circulation was arrested, and cerebral protection was obtained by means of right common carotid artery perfusion at a rate of $10 \mathrm{~mL} \cdot \mathrm{kg}^{-1} \cdot \mathrm{min}^{-1}$ through the right subclavian artery. Another tear was found near the origin of the brachiocephalic trunk. The Djumbodis dissection system (Saint Come-Chirurgie, Marseille, France), $9 \mathrm{~cm}$ long, was inserted in the aortic arch and fixed to the aortic wall with 4 transfixed stitches. The device consists of an uncovered stent made of Steel $316 \mathrm{~L}$ provided in 3 lengths $(4,9$, and $14 \mathrm{~cm})$ and mounted on a compliant balloon (Figure 1). The balloon is inflated to adapt the stent to the shape of the aortic arch and to coapt aortic layers. The deployed device presents a large-meshed web and can be superimposed at the origin of the epiaortic vessels without any danger of obstruction. A $30^{\circ} 5-\mathrm{mm}$ endoscope positioned in the aortic arch allowed us to control the correct deployment of the Djumbodis system. The distal end of a Dacron graft was anastomosed to the distal aortic stump and reconstructed with the same technique as used with the proximal one. Extracorporeal circulation was restored, and proximal anastomosis of the Dacron graft was performed during rewarming of the patient. Selective antegrade cerebral perfusion time was 28 minutes, and aortic arch inspection requires 4 minutes of total circulatory arrest. Contrast-enhanced computed tomographic (CT) scanning showed no patent false lumen in the aortic arch. The patient was discharged in an asymptomatic state 12 days after the operation. At 2 months' follow-up CT scanning, a dilation of the false lumen with an aortic isthmian pseudoaneurysm was found: the patient underwent endovascular thoracic stent graft insertion $(2$ segments, $32 \times 32 \times 230$; Talent World Medical Manufacturing Corp, Sunrise, Fla) through the left femoral artery. Stent grafts were proximally positioned with partial overlapping to the distal end of the Djumbodis dissection system 


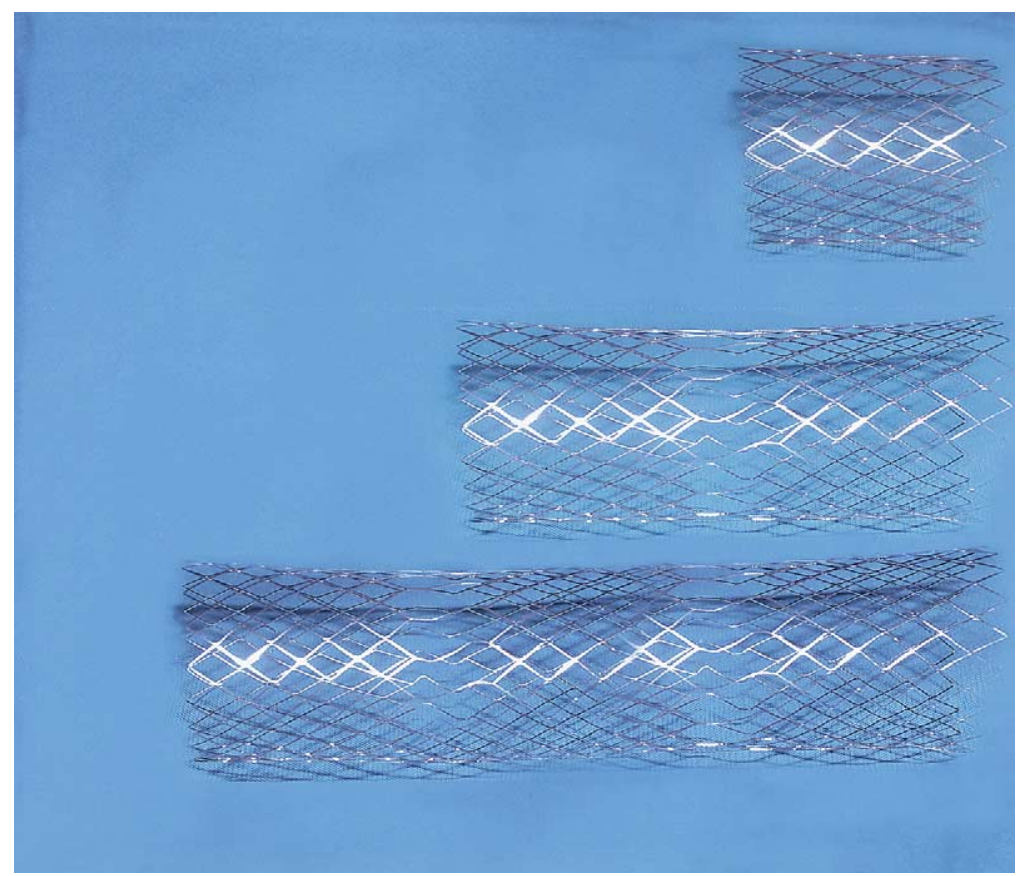

Figure 1. Djumbodis dissection system consisting of an uncovered stent made of Steel $316 \mathrm{~L}$ provided in 3 lengths $(4,9$, and $14 \mathrm{~cm})$.

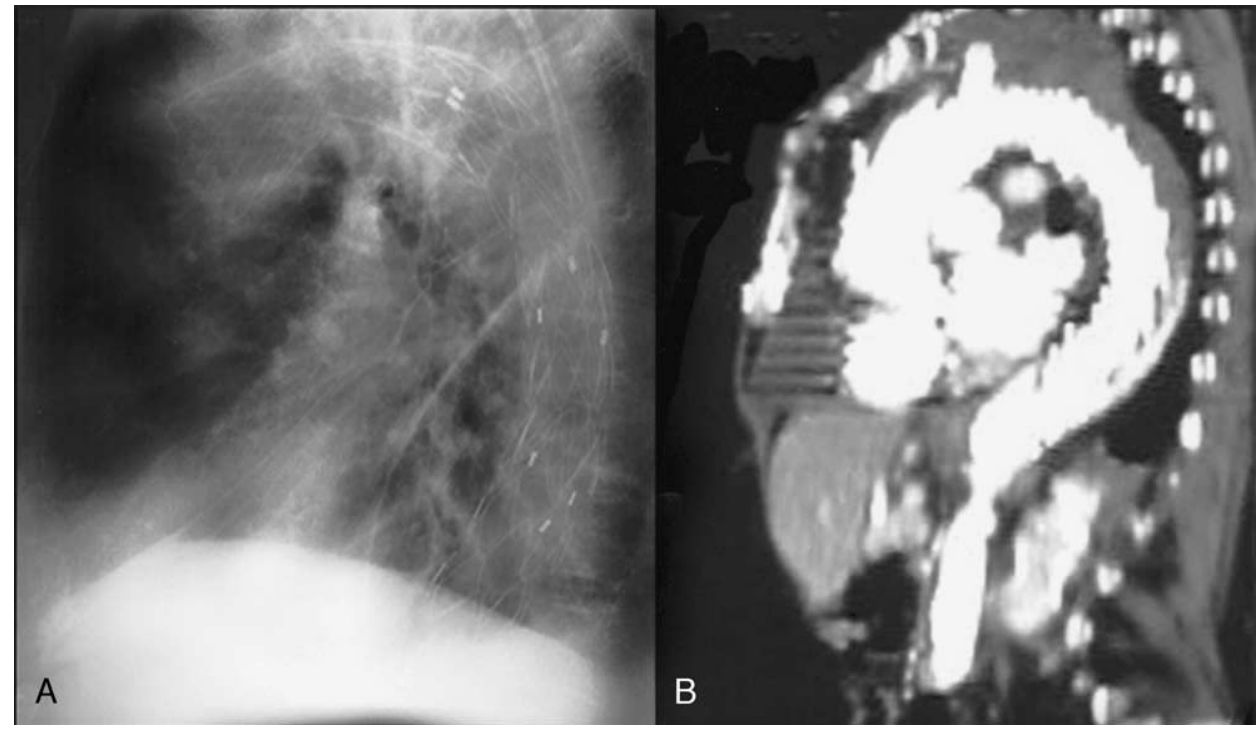

Figure 2. A, Postoperative chest radiograph showing complete correction after placement of a Djumbodis stent and deployment of a thoracic aortic stent graft. B, Postoperative CT scan after complete correction.

and deployed distally up to the origin of the celiac trunk (Figure 2). The postoperative course was uneventful.

\section{Discussion}

The treatment of a type A aortic dissection with aortic arch replacement is reserved for situations in which an intimal tear is located in the transverse arch. Ascending aorta replacement alone remains at considerable risk of future complications (50\%-70\% rate of patent false lumen in the arch and $23 \%$ rate of redo). ${ }^{1}$ Recent reports have shown encouraging results in extended aortic replacement in acute type A dissection, even if this procedure remains a complex technique with a high mortality rate. ${ }^{2,3}$ Roux and colleagues ${ }^{4}$ have reported the use of surgical technique plus stent positioning to treat 2 patients affected by type A aortic 
dissection. In this patient we used a 2-step combined technique: first, positioning of the Djumbodis stent with traditional ascending aorta replacement to avoid surgical aortic arch correction with a relatively easy and reproducible technique; second, transfemoral artery stent grafting of the thoracic aorta to correct pseudoaneurysm and residual dissection. It appears to be a useful procedure mainly in high-risk situations, such as elderly patients with comorbidities in whom aortic arch replacement has a prohibitive surgical risk. The Djumbodis system has also facilitated distal aortic procedures because the long steel stent permits a safe proximal landing zone for deployment of thoracic aortic stent grafts. Control CT scans 2 and 5 months after the last procedure showed the perfect position of the Djumbodis and thoracic stent grafts; the aortic arch was not dilated, and the resulting pseudoaneurysm false lumen was thrombosed. At 7 months' follow-up, the patient is alive and asymptomatic. This combined surgical and endovascular approach might be a valuable adjunct to the treatment of type A aortic dissection, even if midterm follow-up studies will define the clinical outcome of patients subjected to combined solutions for complex aortic disease.

\section{References}

1. Bachet JE, Termignon J, Dreyfus G, Goudot B, Martinelli L, Piquois A, et al. Aortic dissection: prevalence, cause, and results of late reoperations. J Thorac Cardiovasc Surg. 1994;108:199-206.

2. Kazui T, Yamashita K, Washiyama N, Terada H, Bashar AHM, Suzuki T, et al. Impact of an aggressive surgical approach on surgical outcome in type A aortic dissection. Ann Thorac Surg. 2002;74(suppl):S1844-7.

3. Urbanski PP, Siebel A, Zacher M, Hacker RW. Is extended aortic replacement in acute type A dissection justifiable? Ann Thorac Surg. 2003;75:525-9.

4. Roux D, Brouchet L, Concina P, Elghobary T, Glock Y, Fournial G. Type-A acute aortic dissection: combined operation plus stent management. Ann Thorac Surg. 2002;73:1616-8.

\section{Repair of a sinus of Valsalva aneurysm that had ruptured into the pulmonary artery}

Heyman Luckraz, FRCS, ${ }^{a}$ Madhav Naik, FRCS, ${ }^{a}$ Geraint Jenkins, MRCP, and Aprim Youhana, FRCS, ${ }^{a}$ Swansea, United Kingdom

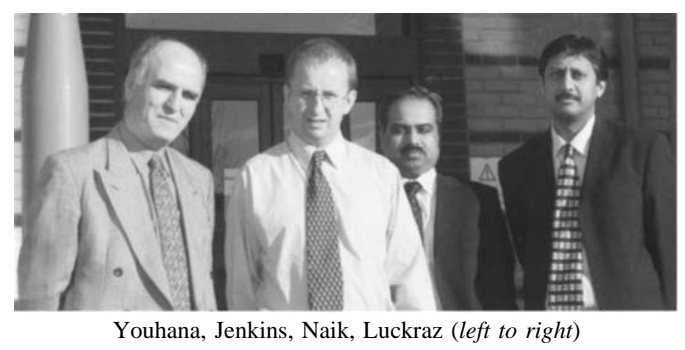

Youhana, Jenkins, Naik, Luckraz (left to right)
$\mathrm{T}$ hus far, less than 500 cases of aneurysmal rupture of the sinus of Valsalva have been reported in the literature, ${ }^{1}$ despite being first reported by Hope in 1839 . The reported prevalence is between $0.14 \%$ and $0.96 \% .{ }^{1}$ Most commonly, the clinical presentation follows the rupture of the aneurysm, although patients without rupture can present with symptoms of a space-occupying lesion causing angina, mitral incompetence, aortic incompetence, and right ventricular outflow tract obstruction.

Surgical repairs were first described independently by Morrow and colleagues ${ }^{2}$ in 1958 and Bigelow and Barnes ${ }^{3}$ in 1959. Two years earlier, Edwards and Burchell ${ }^{4}$ had published a detailed anatomicopathologic review of aneurysms of the aortic sinus. They

\footnotetext{
From the Cardiothoracic Unit ${ }^{a}$ and the Cardiology Department, ${ }^{\mathrm{b}}$ Regional Cardiac Centre, Morriston Hospital, Swansea, United Kingdom.

Received for publication Nov 18, 2003; accepted for publication Nov 24, 2003.

Address for reprints: Heyman Luckraz, FRCS, Cardiothoracic Unit, Morriston Hospital, Swansea SA6 6NL, United Kingdom (E-mail: HeymanLuckraz@aol.com).

J Thorac Cardiovasc Surg 2004;127:1823-5

$0022-5223 / \$ 30.00$

Copyright $\odot 2004$ by The American Association for Thoracic Surgery doi:10.1016/j.jtcvs.2003.11.074
}

described the lesion as being a separation between the aortic media and the heart. This might be due to either a congenital deficiency in the development of the media of the distal bulbar septum or an acquired medial degeneration caused by atherosclerosis, syphilis, and infection.

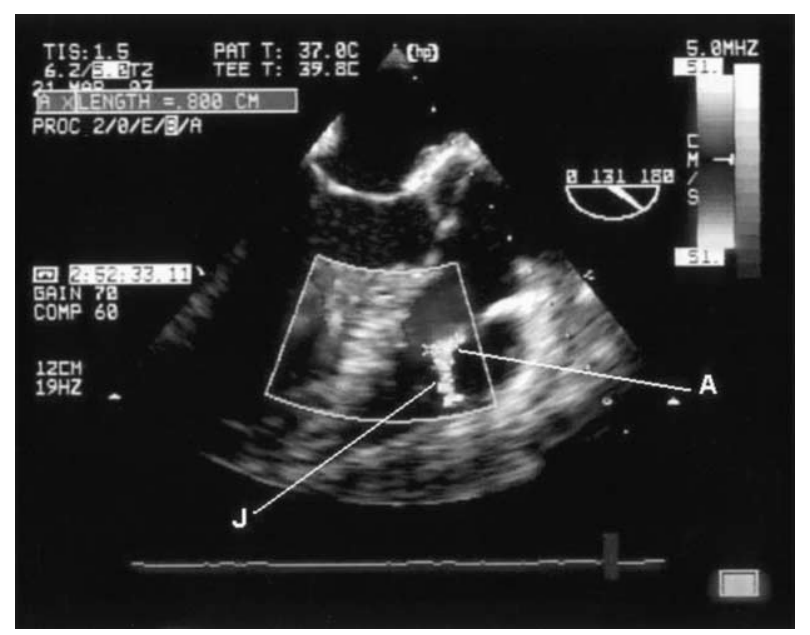

Figure 1. Transthoracic echocardiography showing the level of the aneurysmal rupture $(A)$ with an abnormal jet $(J)$ of blood from the aortic root to the main pulmonary artery. 